\title{
Revista Brasileira de Anestesiologia Bilingue e On-Line: Exposicão e Responsabilidade
}

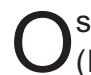
avanços da Revista Brasileira de Anestesiologia RBA) nos últimos anos foram notáveis. A periodicidade, a pontualidade e a qualidade gráfica de sua apresentação são incontestáveis. Ganhou corpo e consistência, graças à contribuição sistemática de autores e excelente trabalho editorial. Gradualmente, se internacionalizou. Inicialmente, por meio de uma publicação anual em inglês dos seus trabalhos mais relevantes (Brazilian Journal of Anesthesiology International Issue, 1990-2000). Finalmente, em 2001 , consagrou-se como publicação bilingüe português-inglês. O próximo passo, conseqüência natural, colocou a RBA na internet. Ganhamos versão on-line. A RBA se expõe à comunidade médica internacional em condições de igualdade com outros periódicos de primeira grandeza.

Aevolução da RBA foi uma jornada longa, difícil, gratificante, e ainda não terminou. Há muito por fazer. Estar on-line aumenta nossa exposição, mas aumenta também nossa responsabilidade. Exige que o material nela veiculado seja apresentado de acordo com um padrão internacional estabelecido. É fundamental que estar on-line signifique inclusão efetiva na comunidade científica internacional. A literatura hoje é lida de forma sistemática e comparativa. Isso se reflete claramente no poderoso instrumento atual de integração de dados, as metanálises. Elas selecionam, para inclusão em seu banco de dados, apenas publicações que contenham informações mínimas que garantam a reprodutibilidade e comparatividade dos dados.

Para estar incluído é preciso comunicar-se nas línguas oficiais da ciência. Algumas fontes têm sido amplamente divulgadas e utilizadas como instrumento para garantir a sistematização da apresentação de resultados de ensaios clínicos aleatórios ${ }^{1-3}$. Uma delas, talvez a mais utilizada, é a The Consolidation of Standards of Reporting Trials CONSORT Statement ${ }^{1,2}$. Essas diretrizes são também fundamentais nos estudos observacionais. Em setembro próximo passado, especialistas se reuniram em Bristol para discutir as bases de um novo documento, o STROBE, the Standards for the Reporting of Observational Studies in Epidemiology ${ }^{4}$. O STROBE tentará sistematizar a apresentação de estudos populacionais (cohort) e tipo caso-controle.

É impossível hoje publicar-se um artigo em periódico de grande impacto sem que o estudo tenha sido planejado e analisado de acordo com requisitos rigorosos. Não pode e não deve ser diferente com a RBA. Entre eles, podemos citar: a) o processo de seleção dos casos; b) os critérios de elegibilidade dos casos; c) o tipo de encobrimento; d) os detalhes precisos das intervenções; d) as hipóteses específicas; e) o atributo primário e os atributos secundários a serem estudados; e) os critérios de determinação do tamanho da amostra e f) a definição clara dos métodos estatísticos utilizados. O cumprimento dessas diretrizes é responsabilidade de autores e editores. Autores devem planejar seus estudos com método apurado e esmerar-se para que os resultados sejam bem analisados e as conclusões bem fundamentadas. Editores devem garantir que essas informações sejam explícitas no texto, cumprindo ao mesmo tempo função de policiamento e educativa. ARBA, por meio de seu Corpo Editorial, tem a responsabilidade de zelar pela qualidade da informação publicada em suas páginas. Hoje, essa informação não mais atinge somente os anestesiologistas de língua portuguesa. Publicada em inglês e disponível on-line, nossa revista está tão acessível à comunidade médica internacional quanto os periódicos de maior impacto de nossa especialidade.

A Anestesiologia brasileira detém características ímpares, experiência clínica fenomenal e propostas inovadoras. A RBAestá pronta para comunicar essa experiência ao mundo. Para isso, ainda temos uma etapa a vencer. Não basta que ela seja publicidade em inglês. É preciso que ela se adapte à estrutura e à linguagem que a comunidade internacional exige ler. Estar on-line em inglês é uma responsabilidade muito grande para a comunidade anestesiológica brasileira. Responsabilidade essa que deve ser repartida entre a Sociedade Brasileira de Anestesiologia, a universidade, os centros de ensino e treinamento, os autores e o corpo editorial da Revista Brasileira de Anestesiologia.

Dr. José Carlos Almeida Carvalho, TSA, PhD, FANZCA, FRCPC Professor Associado de Anestesia em Ginecologia e Obstetrícia, Universidade de Toronto

Diretor de Anestesia em Obstetrícia do Hospital Mount Sinai

\section{Revista Brasileira de Anestesiologia, Bilingual and On-Line: Exposure and Responsibility}

The advances of the Revista Brasileira de Anestesiologia (RBA) in the last decade have been outstanding. The consistency, the punctuality and the graphical quality of its presentation are undeniable. It has gained diversity and depth, thanks to the systematic contribution of authors and excellent editorial work. It has gradually become an international journal. Initially, by means of an annual issue published in English, containing its most relevant original articles (Brazilian Journal of Anesthesiology International Issue, 1990-2000). Finally, in 2001, it established itself as a bilingual Portuguese-English publication. The next step, a natural consequence, was to put the RBAon the Internet. An on-line version is available. The RBA now exposes itself to the international 
medical community to the same extent as other prestigious journals.

The evolution of the RBA has been a long, hard, rewarding journey and has not yet ended. There is much to be done. Being on-line increases our exposure, but also increases our responsibility. It requires its content to be presented in accordance with a well established standard. It is critical that being on-line will translate into a meaningful inclusion into the international scientific community. The literature today is read in a systematic and comparative way. This is clearly reflected in the current powerful instrument of data integration, the meta-analysis. It selects only publications which contain essential information to allow for reproducibility and comparison of data.

In order to be included in the scientific community it is essential to communicate in the official languages of science. A few sources have been widely promoted and utilized as instruments to guarantee the systematic presentation of results of randomized controlled trials ${ }^{1-3}$. One of them, probably the most used, is The Consolidation of Standards of Reporting Trials CONSORT Statement ${ }^{1,2}$. These directives are also essential in the observational studies. Last September, specialists met in Bristol to discuss the fundamentals of a new document, the STROBE, the Standards for the Reporting of Observational Studies in Epidemiology ${ }^{4}$. The STROBE will try to standardize the presentation of data of cohort and case-control studies.

It is impossible nowadays to have an article published in a high-impact journal unless the study has been planned and analyzed according to strict requirements. It cannot be different and it must not be different with the RBA. Amongst other, we can include: a) allocation process; b) eligibility criteria; c) blinding; d) precise details of interventions; d) specific hypothesis; e) clear definition of primary and secondary outcomes; e) sample size determination and f) clear explanation of statistical methods.

The compliance with these directives is a responsibility of both authors and editors. Authors must design their studies with rigorous method, ensure that the results are well analyzed and the conclusions well founded. Editors must guaran- tee that this information is explicit in the text, a role which serves purposes of enforcement and education. The RBA, by means of its Editorial Board, has the responsibility to control the quality of the information which is published in its pages. Today, this information no longer reaches only the Portuguese-speaking anesthesiologists. Published in English and available on-line, our journal is as accessible to the international medical community as any other prestigious journal of our specialty.

The science of Anesthesiology in Brazil holds unique characteristics, phenomenal clinical experience and innovative propositions. The RBA is ready to communicate this experience to the world. For this to happen, there is one more step to overcome. Being published in English is not enough. It is necessary to adapt to the structure and to the language that the international community demands to read. Being on-line is an enormous responsibility to the Brazilian Anesthesiology community. Responsibility which must be shared by the Brazilian Society of Anesthesiology, the University, the Anesthesia Residency Programs, authors and editorial board of the Revista Brasileira de Anestesiologia.

José Carlos Almeida Carvalho, MD, PhD, FANZCA, FRCPC Associate Professor of Anesthesia and Gynecology and Obstetrics, University of Toronto

Director, Obstetric Anesthesia, Mount Sinai Hospital

\section{REFERÊNCIAS - REFERENCES}

01. Moher D, Schulz KF, Altman D - The CONSORT Group. The CONSORT statement: revised recommendations for improving the quality of reports of parallel-group randomized trials. JAMA, 2001;285:1987-1991.

02. http://jama.ama-assn.org/cgi/content/short/285/15/1987.

03. International Committee of Medical Journal Editors. Uniform requirements for manuscripts submitted to biomedical journals: writing and editing for biomedical publications. Available at: http:/www.icmje.org.

04. http:/www.strobe-statement.org. 